\title{
PENGARUH ABU AMPAS KOPI TERHADAP KUAT TEKAN, POROSITAS SEBAGAI PENGGANTI SEMEN PADA PEMBUATAN BETON
}

\author{
Ataya Nabila Panjaitan ${ }^{1}$, Rizky Suci Ramadhani ${ }^{2}$, Ernie Shinta Y Sitanggang ${ }^{3}$ \\ ${ }^{1}$ Program Studi Teknik Perancangan Jalan dan Jembatan, Politeknik Negeri Medan \\ Email: atayapanjaitan@students.polmed.ac.id \\ ${ }^{2}$ Program Studi Teknik Perancangan Jalan dan Jembatan, Politeknik Negeri Medan \\ ${ }^{3}$ Program Studi Teknik Sipil, Politeknik Negeri Medan
}

\begin{abstract}
Abstrak. Ampas kopi juga merupakan limbah industri pangan yang dihasilkan dari pengolahan biji kopi. Sebagaimana halnya limbah industri pangan yang lain, maka limbah ampas kopi mempunyai potensi dimanfaatkan sebagai material substitusi sebagian semen atau agregat halus yang bersifat pozzolan yang mengandung silika. Pada penelitian ini, abu ampas kopi digunakan sebagai material pengganti sebagian semen sebesar 5\%, 10\%, 15\% dan 20\%. Ampas kopi yang digunakan berupa abu dan diayak dengan saringan No. 100. Benda uji berbentuk silinder dengan dimensi $30 \mathrm{~cm}$ x $15 \mathrm{~cm}$ dengan masingmasing variasi 5 buah benda uji untuk 2 pengujian yaitu kuat tekan dan porositas. Kuat tekan rencana beton adalah f'c 25 (beton normal). Pengujian kuat tekan dan porositas dilakukan pada saat umur beton 28 hari.Nilai kuat tekan beton normal sebesar $25.10543 \mathrm{MPa}$. Nilai kuat tekan beton menggunakan abu ampas kopi dengan persentase $5 \%$ sebesar 25.18956 MPa, persentase $10 \%$ sebesar 20.79872 MPa, persentase $15 \%$ sebesar 17.10117 $\mathrm{MPa}$, dan persentase $20 \%$ sebesar 13.28807 MPa. Nilai porositas beton normal sebesar 0.592212 $\%$. Nilai porositas beton menggunakan abu ampas kopi dengan persentase $5 \%$ sebesar 0.690914 $\%$, persentase $10 \%$ sebesar $0.736974 \%$, persentase $15 \%$ sebesar $0.756715 \%$, dan persentase 20 $\%$ sebesar $0.789615 \%$.
\end{abstract}

Kata kunci: Semen, Ampas Kopi, Kuat Tekan.

Diterima Redaksi: 04-10-2020 | Selesai Revisi: 08-03-2021 | Diterbitkan Online: 09-03-2021

\section{PENDAHULUAN}

Beton merupakan salah satu bahan konstruksi yang telah umum digunakan untuk pembangunan gedung, jembatan, dan jalan. Beton merupakan satu kesatuan yang homogen. Beton ini didapatkan dengan cara mencampur agregat halus (pasir), agregat kasar (kerikil), atau jenis agregat lain dan air, dengan semen Portland dan semen hidrolik yang lain terkadang ditambahkan pula dengan bahan tambahan (additive) yang bersifat kimiawi ataupun fisikal pada perbandingan tertentu sampai menjadi satu kesatuan yang homogen. Campuran tersebut akan mengeras seperti batuan. Pengerasan terjadi karena peristiwa reaksi kimia antara semen dan air.

Perkerasan kaku (rigid pavement) adalah jenis perkerasan jalan yang menggunakan beton sebagai bahan utama perkerasan tersebut, perkerasan kaku merupakan salah satu jenis perkerasan jalan yang sering digunakan selain dari perkerasan lentur (asphalt). Perkerasan ini umumnya dipakai pada jalan yang memiliki kondisi lalu lintas yang cukup padat dan memiliki distribusi beban yang besar, seperti pada jalan - jalan lintas antar provinsi, jembatan layang, jalan tol, maupun pada persimpangan bersinyal.

Pozzolan adalah bahan yang mengandung senyawa silika dan alumina, yang tidak mempunyai sifat semen, 
akan tetapi dalam bentuk halusnya dan dengan adanya air dapat menjadi suatu massa padat yang tidak larut dalam air. Pozzolan dapat digunakan sebagai bahan tambah campuran mortar dengan komposisi tertentu. Komposisi yang optimal memberikan dampak baik terhadap mortar, menjadikan mortar mudah diaduk, lebih kedap air, dan kuat tekan mortar menjadi lebih kuat (Tjokrodimuljo, 1996).

Reaksi kimia semen dan air selain menghasilkan Kalcium Silikat Hidrat (CSH), juga membentuk senyawa kimia lain yaitu Kalsium Hidroksida $(\mathrm{Ca}(\mathrm{OH}) 2)$. Senyawa ini bersifat basa dan bereaksi hebat dengan berbagai asam sehingga dapat merugikan dan menurunkan kualitas atau mutu beton. Agar efek tersebut dapat dikurangi, maka dalam adukan beton ditambah bahan yang bersifat posolan (pozzolanic material).

Sebagaimana halnya limbah industri pangan yang lain, limbah ampas kopi mempunyai potensi dimanfaatkan sebagai material substitusi sebagian semen atau agregat halus yang bersifat pozzolan yang mengandung silica dan memiliki partikel yang halus. Bahan yang terdapat dari sisa pembakaran dari tungku maupun pemanfaatan limbah yang diolah menjadi abu yang mengandung silica aktif. Silica merupakan material yang mengandung kadar $\mathrm{SiO} 2$ yang tinggi, sehingga jika ditinjau dari sifat mekaniknya, silica mengisi rongga diantara bahan semen. Pengisian rongga-rongga dalam beton ini berdampak pada peningkatan kuat tekan beton secara signifikan. Penggunaan silica dalam beton akan memberikan dampak peningkatan kuat tekan beton jauh lebih besar. Sisa-sisa dari pengolahan pangan terutama minuman ini termasuk material yang dapat digunakan sebagai bahan tambah untuk kuat tekan beton (Alkhaly R. Yulius, Syahfitri Meutia, 2016).

\section{METODE PENELITIAN}

Pelaksanaan penelitian dibagi ke dalam beberapa tahap yaitu: melakukan persiapan, kemudian melakukan uji bahan dan membuat benda uji, setelah itu dilakukan perawatan beton, lalu dilakukan tes pengujian kuat tekan dan porositas terhadap beton untuk kemudian data dianalisis dan mendapat kesimpulan dan saran.

Untuk mendapatkan hasil dan jawaban dari penelitian yang akan dilakukan, maka diperlukan langkahlangkah dan prosedur yang sistematis. Penelitian ini terdiri dari pengumpulan dan analisis data. Metode yang dilaksanakan dalam penelitian ini adalah metode eksperimental yang akan menegaskan hubungan antara hasil yang akan diselidiki. Lokasi penelitian tugas akhir dilaksanakan di Laboratorium Jurusan Teknik Sipil, Politeknik Negeri Medan.

\section{HASIL DAN PEMBAHASAN}

Hasil pengujian kuat tekan beton didapat sesuai Tabel 1:

Tabel 1: Hasil pengujian kuat tekan beton

\begin{tabular}{ccc}
\hline No & Persen abu & Nilai Kuat Tekan (MPa) \\
\hline 1 & $0 \%$ & 25.10543 \\
2 & $5 \%$ & 25.18956 \\
3 & $10 \%$ & 20.79872 \\
4 & $15 \%$ & 17.10117 \\
5 & $20 \%$ & 13.28807 \\
\hline
\end{tabular}


Dan untuk hasil pengujian porositas beton sesuai Tabel 2.

Tabel 2: Hasil pengujian porositas beton

\begin{tabular}{ccc}
\hline No & Persen abu & Nilai Porositas (\%) \\
\hline 1 & $0 \%$ & 0.592212 \\
2 & $5 \%$ & 0.690914 \\
3 & $10 \%$ & 0.736974 \\
4 & $15 \%$ & 0.756715 \\
5 & $20 \%$ & 0.789615 \\
\hline
\end{tabular}

Dengan memanfaatkan fasilitas trendline pada Microsoft Excel maka dapat diperoleh regresi dari data variasi kadar penggantian agregat halus dengan abu ampas kopi dengan data pengujian kuat tekan beton.

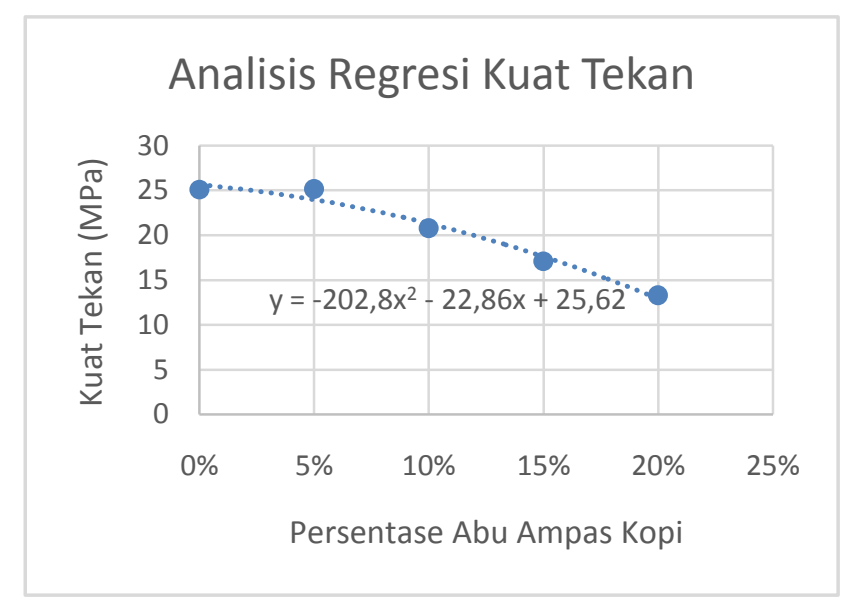

Gambar 1: Grafik Regresi Nilai Kuat Tekan Beton Dengan Variasi Persen Abu Ampas Kopi

Nilai Y Sesuai Pers. 1

$Y=-202.89 x^{2}-22.868 x+25.627$

Dimana:

$\mathrm{Y}=$ Kuat Tekan Beton $(\mathrm{MPa})$

$\mathrm{X}=$ Kadar Penggantian Semen Dengan Abu Ampas Kopi (\%)

$\mathrm{K}$ minimum terjadi pada $\mathrm{dP} / \mathrm{d}(\mathrm{X})-0$

Maka dK/d(X) $=-405,78(X)-22,868$

Dari persamaan di atas diperoleh nilai $\mathrm{X}$ sebagai berikut :

$X=\frac{22,868}{405,78}$

$X=0,0564$ 
Dengan memasukkan nilai $X$ ke persamaan awal maka diperoleh :

$Y=-202,89(0,0564)^{2}-22.868(0,0564)+25.627=23,6919$

Dari hasil perhitungan diambil nilai $\mathrm{X}=0,0564$ yang berarti kadar penggantian semen dengan abu ampas kopi yang optimum adalah sebesar $0,0564 \%$ yang akan menghasilkan nilai kuat tekan beton minimum (P) sebesar 23,6919 MPa.

Penambahan abu ampas kopi pada campuran beton tidak begitu mampu mengurangi porositas beton dan meningkatkan kuat tekan beton sebab abu ampas kopi dengan takaran yang semakin tinggi menyebabkan pori pada beton semakin tinggi pula. Hal ini dikarenakan abu ampas kopi yang digunakan dalam porsi yang banyak tidak dapat menggantikan sifat halus yang dimiliki semen. Oleh karena itu abu ampas kopi terhadap porositas beton tidak memiliki keuntungan, apalagi jika abu yang digunakan dalam jumlah yang banyak. Akan tetapi, untuk persentase penggunaan abu ampas kopi yang kecil dapat memungkinkan, dikarenakan kekuatan tekan dari persentase abu ampas kopi yang kecil meningkat dari beton normal.

Dari nilai yang didapat diharapkan abu ampas kopi dengan persentase yang sedikit dapat meminimalisir besar pori untuk perkerasan kaku (rigid pavement). Namun untuk persentase abu ampas kopi yang besar dibandingkan dengan nilai porositas yang tinggi dari beton normal, maka pengaplikasiannya kepada perkerasan kaku (rigid pavement) tidak dapat dilakukan karena dapat mengurangi nilai ketahanan dan kekuatan pada beton dan tidak dapat meminimalisir rembesan air ke dalam pori beton yang kemudian akan merusak tulangan pada plat perkerasan kaku.

\section{SIMPULAN}

Nilai kuat tekan beton normal sebesar 25,105 MPa. Nilai kuat tekan beton menggunakan abu ampas kopi dengan persentase $5 \%$ sebesar 25,189 MPa, persentase $10 \%$ sebesar 20,798 MPa, persentase $15 \%$ sebesar 17,101 MPa, dan persentase $20 \%$ sebesar 13,288 MPa. Nilai porositas beton normal sebesar 0,592 \%. Nilai porositas beton menggunakan abu ampas kopi dengan persentase $5 \%$ sebesar $0,690 \%$, persentase $10 \%$ sebesar $0,736 \%$, persentase $15 \%$ sebesar $0,756 \%$, dan persentase $20 \%$ sebesar $0,789 \%$.

Dari hasil perhitungan yang didapat, pembuatan beton dengan f'c 25 untuk perkerasan kaku (rigid pavement) dengan mengganti semen secara parsial dengan abu ampas kopi dan menggunakan takaran persentase yang berbeda yaitu 5\%, 10\%, 15\%, 20\% tidak mendapatkan hasil yang baik. Maka dari itu hasil dari penelitian ini yaitu abu ampas kopi dengan persentase 5\%,10\%,15\%, 20\% tidak dapat digunakan untuk pembuatan beton untuk perkerasan kaku.

\section{DAFTAR PUSTAKA}

Riko, A.F, 2018. Pengaruh Faktor Umur Terhadap Perbandingan Kuat Tekan Beton Normal, Beton Mutu Tinggi Dan Beton Ringan. Jurusan Teknik Sipil, Fakultas Teknik, Universitas Mataram.

Yulius, A.R, Meutia, S., 2016. Studi Eksperimen Penggunaan Abu Ampas Kopi Sebagai Material Pengganti Parsial Semen Pada Pembuatan Beton, Jurusan Teknik Sipil, Fakultas Teknik Universitas Malikussaleh. 
Tjokrodimulyo, K. 2004. Teknologi Beton. Yogyakarta: Andi.

Dinda, A.M. 2019. Pengaruh Umur Terhadap Kuat Tekan Beton Menggunakan Semen PCC. Tugas Akhir, Jurusan Teknik Sipil, Fakultas Teknik, Politeknik Negeri Medan.

Tania, C. 2018. Pengaruh Penambahan Abu Vulkanik Terhadap Kuat Tekan dan Porositas Beton. Tugas Akhir, Jurusan Teknik Sipil, Fakultas Teknik, Politeknik Negeri Medan.

Sundari Y. 2012. Pengaruh Umur Beton Terhadap Nilai Kuat Tekan Pada Mutu Beton. Media Sains, Volume 4 Nomor 1 April 2012 : Sains 